\title{
Seção Generalista
}

\section{Social skills of gifted and talented children}

\author{
Maria Luiza Pontes de França-Freitas \\ Universidade Federal do Rio Grande do Norte \\ Almir Del Prette \\ Zilda Aparecida Pereira Del Prette \\ Universidade Federal de São Carlos
}

\begin{abstract}
There is a clear lack of empirical studies about the socio-emotional characteristics of gifted and talented children, especially in the context of social skills. This study aimed to characterize the social skills of such children, identifying similarities and differences in the skill repertoire in comparison with non-gifted children. The sample contained 394 children from 8 to 12 years old, of which 269 children were identified as gifted. All participants answered the Social Skills Rating System and Socio-demographic Questionnaire. The results indicate a more elaborate social skills repertoire for gifted children in all categories with the exception of empathic skills. The implications of these results for the planning of educational programs are discussed and future research directions are identified.
\end{abstract}

Keywords: social skills; giftedness; talent.

\section{Resumo}

Habilidades sociais de crianças dotadas e talentosas. A literatura apresenta escassez de estudos empíricos e controvérsias sobre as características socioemocionais de crianças dotadas e talentosas, especialmente no âmbito das habilidades sociais. Este estudo visou caracterizar o repertório de habilidades sociais dessas crianças e identificar semelhanças e diferenças em relação ao repertório de crianças não dotadas. Participaram 394 crianças de oito a 12 anos e, dentre essas, 269 identificadas como dotadas. Todos os participantes responderam ao Sistema de Avaliação de Habilidades Sociais e ao Questionário Sociodemográfico. Os resultados indicaram um repertório mais elaborado de habilidades sociais para as crianças dotadas em todas as classes, exceto nas empáticas. Discutem-se implicações desses resultados para o planejamento de programas educacionais bem como questões adicionais para futuras pesquisas nessa temática.

Palavras-chave: habilidades sociais; dotação; talento.

\section{Resumen}

Habilidades sociales de niños dotados y talentosos. La literatura presenta una escasez de estudios empíricos y controversias sobre las características socioemocionales de niños dotados y talentosos, especialmente en el ámbito de las habilidades sociales. Este estudio tuvo, como objetivos, caracterizar el repertorio de habilidades sociales de esos niños e identificar semejanzas y diferencias en relación al repertorio de niños no dotados. Participaron 394 niños de ocho a doce años, de los cuales 269 fueron identificados como dotados. Los participantes respondieron al Sistema de Evaluación de Habilidades Sociales y al Cuestionario Sociodemográfico. Los resultados indicaron un repertorio más elaborado de habilidades sociales para los niños dotados en todas las clases, excepto en las empáticas. Son discutidas implicaciones de esos resultados para el planeamiento de programas educacionales, así como cuestiones adicionales para futuras investigaciones sobre ese tema.

Palabras claves: habilidades sociales; dotación; talento.

iftedness and talent have been only briefly discussed in the Brazilian context in comparison to other Special Education topics. Moreover, the researchers in this area typically utilize different concepts and terms to refer to the giftedness and talent (Gagné, 2009; Gardner, 1994; Guenther, 2006; Renzulli, 1998; Sternberg, 2003). Here, we adopt Gagné's (2005) definitions: giftedness is the relatively higher capacity of an individual in, at least, one domain of human ability - general intelligence, creativity, socio-affective ability, sensorimotor ability. In contrast, talent is defined as an above average performance in a particular field. Gagné (2005) considers that giftedness has an internal origin and organization, being related to brain functioning and based in specific domains of human ability, aptitudes and attributes; talent is Acervo disponivel em: www.scielo.br/epsic 
the measurable expression of these abilities that has been developed under a given set of environmental conditions.

Brazilian research of giftedness and talent has mainly focused on education, public policies, identification of gifted children, and programs to stimulate development and creativity (e.g. Alencar, 2007b; Fleith, 2006; Guenther, 2007), with very few studies addressing the socio-emotional characteristics of gifted and talented children. This pattern is repeated in the international literature, where there is a very limited number of recent studies in this research area (Bain \& Bell, 2004; Bain, Choate, \& Bliss, 2006; Gross, 2002; Lehman \& Erdwins, 2004; Moon, 2004; Norman, Ramsay, Roberts, \& Martray, 2000; Silverman, 2002; Versteynen, 2001). Moreover, these studies have frequently generated conflicting results, possibly as a result of conflicting hypotheses about social adjustment in gifted children. While some researchers consider gifted children to be more prone to socio-emotional adjustment problems, other researchers assume that gifted children generally will, as a consequence of their gifts, have better capacity for socio-emotional adjustment (reviewed in Neihart, 1999; Richards, Encel, \& Shute, 2003; Webb, 1993).

Specifically, many researchers believe that gifted individuals have a higher risk of emotional and social problems, particularly during adolescence and early adulthood (Neihart, 1999). Under this model, gifted individuals are more sensitive to interpersonal conflicts and subject to higher stress levels than their peers due to their cognitive abilities, and consequently feel more depressed, anxious and suffer from low self-esteem (e.g., Cross, 1998; Cross, Coleman, \& Stewart, 1995; Gross, 2002, 2004; Moon, 2004, 2009; Peterson, 2009; Peterson, Duncan \& Canady, 2009; Silverman, 2002). Such characteristics would lead to difficulties in establishing positive social relationships. Under the contrasting hypothesis, researchers consider gifted children to be better able to understand themselves and others due to their elevated cognitive abilities and, therefore, to be better equipped to deal with stress and social conflict (Neihart, 1999). Thus, several studies suggest that gifted children show better socio-emotional adjustment than their non-gifted colleagues in terms of depression and social competence (Bain \& Bell, 2004; Baker, 2004; Howard-Hamilton \& Franks, 1995; McCallister, Nash, \& Meckestroth, 1996; Merrell, Gil, McFarland, \& McFarland, 1996; Nail \& Evan, 1997, Neihart, 1999; Robinson \& Noble, 1992; Sowa et al., 1994; Versteynen, 2001).

A possible approach for the socio-emotional analysis of gifted and talented children is through the study of social skills and social competences. According to Del Prette and Del Prette (2001, 2008), 'social skills' relate to the different classes of an individual's social behavior that contribute to the quality and effectiveness of interactions that they establish with others. 'Social competence' is the individual's ability to articulate feelings, thoughts and behaviors, depending on personal goals and situational and cultural demands, with favorable consequences for the individual and their relationship with others (Del Prette \& Del Prette, 2001; Del Prette \& Del Prette, 2005).
Higher levels of social skills and social competence are associated with better quality of life, more rewarding interpersonal relationships, greater personal fulfilment, professional success, and better physical and mental health (Bandeira, Del Prette, Del Prette, \& Magalhães 2009; Lehman \& Erdwins, 2004). Children with positive interpersonal characteristics (high self-esteem, academic or non-academic self-concept, social competence and, empathy and problem solving skills) are more likely to achieve a satisfactory developmental trajectory (Cia, Pamplin, \& Del Prette, 2006). Conversely, the absence of these characteristics is seen as a risk factor, which can lead to behavioral or emotional problems and other psychosocial problems (Cia et al., 2006; Del Prette \& Del Prette, 2005; Feitosa, 2013; Medeiros \& Loureiro, 2004). Peer relations and social competence are often included in assessments of a child`s psychological adjustment (Neihart, 1999). Thus, researchers (Bain et al., 2006; Cross et al., 1995; Galloway \& Porath, 1997; Garland \& Zigler, 1999, Norman et al., 2000; Swiatek, 1995) typically address the adjustment of gifted and talented children based on their social status, social skills (especially social coping) and social competence.

Several studies have indicated that gifted and talented children belong to a positively differentiated group in relation to their social skills and social competence (Galloway \& Porath, 1997; Hallahan \& Kauffman, 2003; McCallister et al., 1996). Such children frequently have characteristics common in popular children, including a good social skills repertoire, lack of behavioral problems, leadership skills, and high academic performance and high self-esteem (Bain \& Bell, 2004). For example, Lehman and Erdwins (2004) compared a group of 16 intellectually gifted children with a group of children with average intelligence. Two personality measures were used as indicators of social and emotional adjustment and a range of values and social attitudes were assessed. The high performing group showed better social skills and more mature forms of interaction with others; valuing more democratic and cooperative interactions than the competitive ones. A related study (Field et al., 1998) compared 62 intellectually gifted students (IQ above 132) with 162 non-gifted (mean age 14 years), based on a 'Giftedness Perception Scale' answered by their teachers. The scale had items on academic and social skills (making friends, starting conversation, understanding people, having close friends, making jokes, etc.) and giftedness. Gifted students showed earlier social development and better social skills when compared to their non- gifted peers. Likewise, Czeschlik and Rost (1995) investigated the relationship between intelligence and the five sociometric categories ('popular', 'rejected', 'neglected', 'controversial' and 'average') in a sample of 5861 third grade children from 317 classes. Students with higher IQ were identified as the most popular among their peers. Chagas (2008) investigated the individual and family characteristics of gifted students using the perceptions of their peers, families and teachers. Significantly, gifted children took responsibility for implementing activities and were typically good humored. Richards et al. (2003) compared the emotional and behavioral adjustment of 33 intellectually 
gifted adolescents (identified by IQ) with 25 non-gifted adolescents, using the Behavioral Assessment System for Children (BASC). The intellectually gifted group had higher cognitive maturity, including advanced ability to solve problems and lower levels of behavioural problem than their non-gifted peers. Frydenberg (1997) reported differences in the way that gifted young people deal with their concerns, suggesting a focus on problem solving. Preuss and Dubow (2004) found similar results: gifted students used more problem-solving strategies to deal with stress than non-gifted students. Gifted children also seem to have greater capacity to address problems common to all children, possibly as a result of their giftedness (Sowa et al., 1994).

Indeed, there is no reliable evidence that exceptionally high ability alone is associated with socio-emotional problems (Freeman, 1998). Richards et al. (2003) suggests that claims about the maladjustment of gifted children have been widespread in the literature because the selection of participants in some studies was biased; researchers identified gifted young people who may have been at high risk of maladjustment. For example, young people with other disabilities, female adolescents and adolescents with cultural and linguistic experiences or with low socioeconomic status. Such samples are generally derived from both clinical and case studies and lack appropriate comparison groups. Studies with these sampling characteristics have frequently found socio-emotional difficulties in gifted and talented individuals (Cross, 1998; Cross, Coleman, \& Stewart, 1995; Gross, 2002, 2004; Moon, 2004, 2009; Peterson, 2009; Peterson, Duncan, \& Canady, 2009; Silverman, 2002).

In addition to the contradictions between studies and the general scarcity of publications on socio-emotional characteristics of gifted and talented children (Dai, Swanson, \& Cheng, 2011), there is a strong cultural belief that these children, in general, are not well socially or emotionally adjusted. They are frequently perceived as timid and excessively concerned about academic study, with little social contact and difficulties in their social relations. However, as mentioned, the empirical data do not clearly support (or reject) the hypotheses of social deficit or social advantage of gifted children.

In summary, there is still a very few studies on gifted and talented children, and most of these exclusively focus on the intellectual domain (identified by intelligence quotient tests) to the detriment of other domains such as creativity, socio-affective and sensorimotor abilities. Thus, there is still lack of research on: (a) the more sophisticated classes of social skills in gifted individuals, and; (b) the possible relationships among social skills classes, academic learning and creativity. For example, the skill to ask questions, to answer questions, and to propose activities, etc. In the Brazilian research context, there is a predominance of publications on cognitive characteristics and educational needs of gifted and talented children population, and a considerable lack of empirical research on socio-emotional variables and social skills. Moreover, there is a predominance of clinical case-studies and qualitative research with very small samples, often derived from a single school or program (Alencar, 2007a).
There is clearly a need for quantitative research on social skills of gifted and talented children, using a statistically representative sample. In order to characterize the social skills of these children it is important to understand their socio-emotional needs, for planning educational practices and a greater appreciation of their giftedness. Given the above, the objectives of this study were: (1) to characterize the social skills repertoire of gifted and talented children, and; (2) to identify similarities and differences between the social skills repertoire of gifted and non-gifted children.

\section{Method}

This study was approved by the Ethics Committee of the Federal University of São Carlos, meeting the requirements for human research (Protocol: 0668.0.000.135-09). The parents of the participants signed the Informed Consent Form (ICF) and parents and their children received the necessary information to understand the aims of the research.

\section{Sampling}

The sample consisted of 394 children (female and male) between 8 and 12 years of age. From this sample, 269 children were identified as gifted and talented, and 125 as non-gifted. The following criterion was used to select gifted and talented participants: giftedness in at least one human ability domain (general intelligence, creativity, ability and socio-affective and sensorimotor ability, as Gagné (2009). Gifted and talented individuals were excluded if they did not undergo the standard process of identification of giftedness and talent in the data collection centers. The research was conducted in regular schools and two centers which have an educational program for gifted and talented students: Center 1 in Lavras and Center 2 in São José dos Campos.

The majority of gifted and talented children enrolled in giftedness and talent development Centers were female (53.2\%) with an average age of 11 years old $(S D=0.911$; range $8-12$ ) from public schools (91.1\%) and were attending the 5th grade of elementary school (50.9\%).The 125 children identified as nongifted were enrolled in regular schools from the Brazilian public school system linked to the Center 2. Most of the children were female $(63 \%)$ with an average age of 11 years old $(S D=0.54)$, and were attending the fifth grade of elementary school. These children attended the same classrooms as the gifted children.

\section{Instruments}

The participants responded to two self-report instruments: a characterization questionnaire and a social skills scale, the Social Skills Rating System (SSRS-BR). The socio-demographic questionnaire contained questions related to the sample characterization, for example: age, gender and school year. The SSRS-BR assesses social skills, problem behaviors, and academic competence and was originally produced in the U.S. (Gresham \& Elliott, 1990) and validated for the Brazilian sample (SSRS-BR, Bandeira et al., 2009). It has 
three versions: version $\mathrm{T}$ for teachers (30 items), version $\mathrm{P}$ for parents ( 37 items), and version $C$ for child ( 27 items). The validation for the Brazilian context showed that SSRS-BR has satisfactory internal consistency, measured by Cronbach's alpha on the scales of social skills (child=0.78; parents $=0.86$; teachers $=0.94$ ); problem behaviors (parents $=0.83$; teachers $=0.94$ ) and academic competence (alpha=0.98). Furthermore, the validation also displayed positive and significant correlations in the test-retest for all scales, demonstrating temporal stability (reliability). In this study, version $C$ (SSRS-C) was used which assesses social skills frequency ( 0 =Never, 1 =Sometimes, $2=$ Very often) and is composed by six factors with eigenvalues between 1.16 and 4.0; thus, explaining $41,65 \%$ of the data variance: (i) "Responsibility" (e.g., I leave my student desk clean and tidy), (ii) "Empathy" (e.g., I try to understand how my friends feel when they are angry, upset or sad), (iii) "Assertiveness" (e.g., I avoid doing things with other people which can let me in trouble with adults), (iv) "Self-control" (e.g., I finish disagreements with my parents calmly), (v) "Problem Avoidance" (e.g., I ignore other children when they tease me or call me names), and (vi) "Expression of Positive Feelings" (e.g., I show or tell my friends that like them). The Measure of Sampling Adequacy was satisfactory $(\mathrm{KMO}=0.79)$, the Bartlett's test of Sphericity displayed significant results $\left(X^{2}=1561.23, d f=378, p\right.$ $=0.00$ ) and was adopted loading factors greater than 0.32 . Considering the standard interpretation of the instrument, the percentile interval from 1 to 50 concerns a lower to medium repertoire, the percentile interval from 51 to 100 regards a good to a highly elaborated repertoire and the percentile interval from 76 to 100 refers to a highly elaborated repertoire.

\section{Procedure}

The questionnaires were administrated to gifted and not-gifted children sample in schools and centers. The responses to SSRS-BR were tabulated as total and factorial scores, according to the guidelines prepared by the Brazilian authors (REF). The data and remaining socioeconomic indicators were transcribed into spreadsheets and analyzed with the Predictive Analytics Statistics Software (PASW Statistics Base for Windows, version 18.0).

\section{Results}

The social skills repertoire of gifted and talented children was based on scores obtained from SSRS-BR and percentile ranks. Table 1 provides the absolute and relative frequency of participants distributed across percentile intervals (1-50, 51100 and 76-100) for each SSRS-BR subscale and for the total score.
Table 1

Absolute and Relative Frequency of Gifted and Talented Children in Each Percentile Interval of Social Skills According to Self-assessment Through the SSRS-BR

\begin{tabular}{ccccccc}
\hline & \multicolumn{6}{c}{ Percentile Intervals } \\
\hline \multirow{2}{*}{ Social Skills } & \multicolumn{2}{c}{$1-50$} & \multicolumn{2}{c}{$51-100$} & \multicolumn{2}{c}{$76-100$} \\
\cline { 2 - 7 } & $\mathrm{N}$ & $\%$ & $\mathrm{~N}$ & $\%$ & $\mathrm{~N}$ & $\%$ \\
\hline HS Global Score & 124 & 46.09 & 145 & 53.91 & 66 & 24.55 \\
F1-Responsibility & 111 & 41.26 & 158 & 58.74 & 61 & 22.69 \\
F2-Empathy & 120 & 44.60 & 149 & 55.40 & 62 & 23.06 \\
F3-Assertiveness & 140 & 52.04 & 129 & 47.96 & 87 & 32.35 \\
F4-Self-control & 130 & 48.32 & 139 & 51.68 & 54 & 20.09 \\
F5-Problems avoidance & 114 & 42.37 & 155 & 57.63 & 82 & 30.50 \\
F6-Expression of Positive & 100 & 37.1 & 169 & 62.83 & 103 & 38.30 \\
Feelings & & & & & & \\
\hline
\end{tabular}

In general, gifted students showed a lower percentage than the normative sample on the lower half of the percentile distribution (below $46 \%$ of the sample, when the expectation is approximately 50\%) and higher than expected in the upper range percentile (51-100). The exception in both cases was for assertiveness factor (F3). Considering the upper end of the scale (76-100, which comprises $25 \%$ of the normative sample), the percentage of gifted and talented children is above the expected level for assertive skills (F3), avoidance of problems (F5) and expression of positive feelings (F6).

In addition to the analysis of percentiles, social skills of gifted children $(N=269)$ and non-gifted $(N=125)$ were compared with the Student's t-test for independent samples (Figure 1 ).

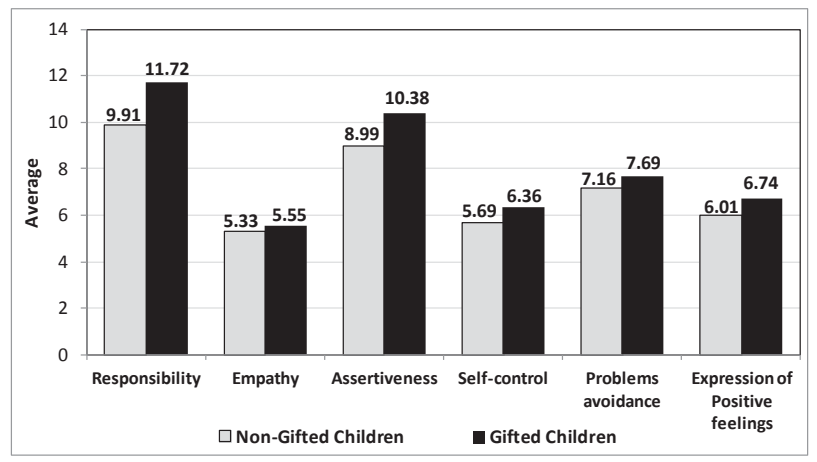

Figure 1. Subscales Average Frequency for the Sample of Gifted and Non-gifted Children.

The results showed a significant advantage $[\mathrm{t}(181.11)=$ -6.53, $p<0.001]$ in the social skills of gifted $(M=41.68, S D$ $=5.36)$ as compared to not-gifted children $(M=36.71, S D$ = 7.76). This difference is statistically significant for all subscales ( $p<0.05$ for Problem Avoidance and $p<0.001$ for all others), except for Empathy [t (190.68) $=-1.32, p=0.188$ ].

In order to refine the analysis, gifted children and non-gifted were compared only for the Center 2 sample $(N=86)$ where the children live in the same town and attend the same regular 
schools $(N=125)$. The results were similar to those obtained with the general sample of children (Center 1 and Center 2), once again showing a lack of difference only in the Empathy subscale.

A weighted average (sum of scores on the items of each subscale divided by the total number of items in each subscale, with mean based on values for each group) was used to compare the subscales hierarchy of social skills among gifted and non-gifted children. The data are illustrated in Figure 2, with the subscales in descending order for gifted children sample.

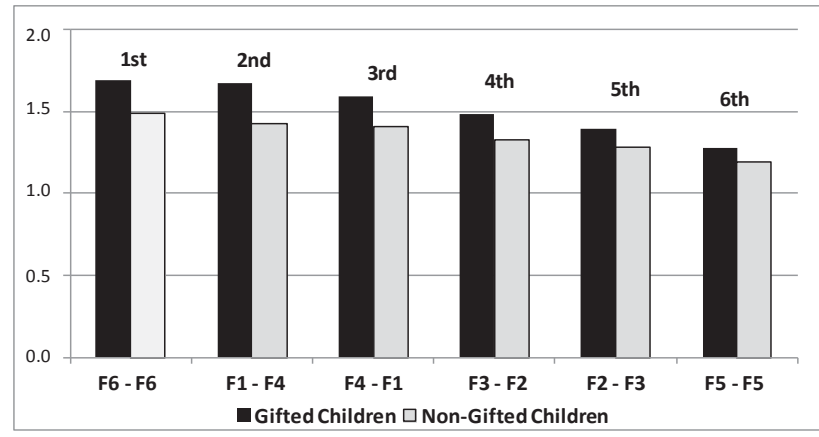

Figure 2. Weighted Averages of the Social Skills Subscales in the Sample of Gifted and Non-gifted Children. F1 = Responsibility; F2=Empathy, F3 $=$ Assertiveness, F4 =Self-control; F5 =Problem Avoidance; F6 = EXpression of Positive Feeling.

The two samples coincided in the class of highest mean score (Expression of Positive Feelings) and the lowest mean score (Problem avoidance). In the other subscales, the sequence of higher scores for gifted children was Responsibility (2nd), Self-control (3rd), Assertiveness (4th) and Empathy (5th), and for the sample of non-gifted children it was Self-control (2nd), Responsibility (3rd), Empathy (4th) and Assertiveness (5th) (see Figure 2).

\section{Discussion}

This study demonstrated the superiority of the social skills repertoire of gifted and talented children compared to non-gifted as measured by the SSRS-BR (overall score and subclasses), with the exception of empathic skills. These results are in complete contrast to the culturally embedded idea that gifted children typically encounter difficulties in their interpersonal relationships (Gross, 2004; Moon, 2009; Peterson, 2009) - at least within the conditions that are demonstrated in their social skills repertoire. Moreover, the results are consistent with those obtained in other studies that classified gifted and talented children as having: (a) greater social competence (Galloway \& Porath, 1997; McCallister et al., 1996); (b) a well-developed social skills repertoire (Field et al., 1998; Lehman \& Erdwins, 2004); (c) superior ability to solve problems (Richards et al., 2003), and; (d) excellent sociometric status (Czeschlik \& Rost, 1995). It seems probable that these skills enable gifted children to feel satisfied with their relationships and quality of life (Bain et al., 2006; Lehman \& Erdwins, 2004).

Gifted and talented children primarily demonstrated a significantly better skill to "Express Positive Feelings". This is a very important skill class for constructing emotional relationships between people (Del Prette \& Del Prette, 2001). However, although related to positive affect expression, there was no difference between gifted children and non-gifted in relation to the "Empathy" social skills subscale. This is interesting, especially considering that empathy was not among the highest scoring in the hierarchy (Figure 2). It is possible that the school and home environments of both groups of children may not be conducive to the development this skills class (Pavarino, Del Prette, \& Del Prette, 2005).

The skills within the "Responsibility" sub-class were the second most favored set for gifted children. There are skills demonstrating commitment to tasks and people within the school environment. This class includes items such as: pay attention when the teacher is teaching and follow his/her instructions, leave the student desk clean and tidy, looking after personal materials; make their own tasks within the allotted time and properly use the free time. This result aligns with studies of Bain and Bell (2004) and Chagas (2008), in which the gifted and talented adolescents reported higher frequency of behaviors indicative of responsibility in carrying out activities.

The "Self-control" skill was one of classes more punctuated by gifted and talented children. This may suggest that in their social interaction, the gifted and talented children can control their emotions, for example, to control their anger at tension times during the interaction, calmly finish fights with theirs parents and listen to adults when they are talking. The gifted child is able to understand himself and others better, as well as to handle stress and conflicts better if compared to their peers (Neihart, 1999). Bain and Bell (2004) and Richards et al. (2003) claim that gifted children have low frequency of behavior problems which may indicate that they have better control of emotions and behaviors.

Both gifted and non-gifted children had the lowest score on Problem Avoidance. This finding is unexpected, since the literature indicates that gifted children have this skill well-developed in their behavioral repertoire (Frydenberg, 1997; Preuss \& Dubow, 2004; Sowa et al., 1994).

\section{Final considerations}

The results obtained with gifted and talented children in Brazil were similar to those generated by empirical research in other countries, indicating that these children should be considered as a distinct group when it comes to social competences (Bain \& Bell, 2004; Baker, 2004; Galloway \& Porath, 1997; McCallister et al., 1996; Neihart, 1999; Versteynen, 2001). A good social skills repertoire helps an individual to develop rewarding interpersonal relationships which, in turn, lead to greater personal and professional success and better physical and mental health (Bandeira et al., 2009; Lehman \& Erdwins, 
2004). Thus, the results suggest that gifted and talented children are typically well adjusted, well suited to assume important positions in society and can generally expect a high quality of life. However, the results contradict long held beliefs that gifted and talented children have more problems and socio-emotional challenges, such as difficulties in establishing satisfactory interpersonal relationships (Cross, 1998; Cross, Coleman, \& Stewart, 1995; Gross, 2002, 2004; Moon, 2004, 2009; Peterson, 2009; Peterson, Duncan, \& Canady, 2009).

Specifically, this study contributes to a growing literature by: (a) highlighting the importance of obtaining additional indicators to assess the social skills repertoire of gifted and non-gifted children; (b) identifying several social skills classes that are better elaborated in gifted and talented children. In this case: Expressing Positive Feelings, Responsibility and Selfcontrol; (c) identifying a less elaborate repertoire of Empathy skills in both gifted and non-gifted children. This information is potentially useful for strengthening educational programs that aim to develop the socio-affective domain of these children.

One limitation of this study is that the results were based only on self-assessment of children. Evaluating multimodal social skills and social competence is strongly recommended by scholars in this area (Del Prette, \& Del Prette, 2009). Thus, further studies comparing different data sources (e.g., parents and teachers) could broaden the understanding of the skills repertoire, helping to identify the behaviour of gifted children in different social contexts (e.g. family and school). In future studies it would be interesting to adopt other experimental designs, such as those that use observational methods (e.g. video recording, self-registers, cursive and duration record cursive, among others). Such an approach may help to refine the assessment of child social competence and reduce some of the potential biases inherent in self-assessment.

The study suggests several profitable avenues for future research with gifted and talented individuals, such as: (a) extending and refining the characterization of the social skills repertoire of gifted and talented children, using different informants and assessment procedures (parents, teachers, peers) and different instruments/procedures (self-report, reports by others, sociometric assessment, observation, etc.); (b) adopting a longitudinal design to characterize the development of this skills repertoire at different times in the individual's life cycle; (c) conducting intervention studies (experimental or quasi-experimental) in order to explore the use that gifted people make of their favorable socio-emotional repertoire in other areas of activity, including those in which they are talented. Most importantly, research should be used to ensure that the needs of especially gifted and talented children are being met at school and at home.

\section{References}

Alencar, E. M. L. S. (2007a). Características sócio-emocionais do superdotado: Questões atuais. Psicologia em Estudo, 12(2), 371-378. doi: 10.1590/ S1413-73722007000200018
Alencar, E. M. L. S. (2007b). Criatividade no contexto educacional: Três décadas de pesquisa. Psicologia: Teoria e Pesquisa, 23(5), 45-49. doi:10.1590/S010237722007000500008

Bain, S. K., \& Bell, S. M. (2004). Social self-concept, social attributions, and peer relationships in fourth, fifth, and sixth graders who are gifted compared to high achievers. Gifted Child Quarterly, 48(3), 168-178. doi: 10.1177/001698620404800302

Bain, S. K., Choate, S. M., \& Bliss, S. L. (2006). Perceptions of developmental, social, and emotional issues in giftedness: Are they realistic? Roeper Review, 29(1), 41-48. doi: 10.1080/02783190609554383

Baker, J. A. (2004). Depression and suicidal ideation among academically gifted adolescents. In S. M. Moon (Ed.), Social/emotional issues, underachievement and counseling of gifted and talented students (pp. 21-30). Thousand Oaks: Corwin.

Bandeira, M., Del Prette, Z. A. P., Del Prette, A., \& Magalhães, T. (2009). Validação das escalas de habilidades sociais, comportamentos problemáticos e competência acadêmica (SSRS-BR) para o ensino fundamental. Psicologia: Teoria e Pesquisa, 25(2), 271-282. doi: 10.1590/ S0102-37722009000200016

Chagas, J. F. (2008). Adolescentes talentosos: Características individuais e familiares (Master Dissertation). University of Brasília, Brasília. Retrieved from http://hdl.handle.net/10482/1227

Cia, F., Pamplin, R. C. O., \& Del Prette, Z. A. P. (2006). Comunicação e participação pais-filhos: Correlação com habilidades sociais e problemas de comportamento dos filhos. Paidéia, 16(35), 395-406. doi: 10.1590/ S0103-863X2006000300010

Czeschlik, T., \& Rost, D. H. (1995). Sociometric types and children's intelligence. British Journal of Developmental Psychology, 13(2), 177-189.

Cross, T. C. (1998). Developing relationships, communication and identity. Gifted Child Today Magazine, 21(5), 28-29.

Cross, T. L., Coleman, L. J., \& Stewart, R. A. (1995). Psychosocial diversity among gifted adolescents: An exploratory study of two groups. Roeper Review, 17(3), 181-185. doi: 10.1080/02783199509553655

Czeschlik, T., \& Rost, D. H. (1995). Sociometric types and children's intelligence. British Journal of Developmental Psychology, 13(2), 177-189. doi: 10.1111/j.2044-835X.1995.tb00672.x

Dai, D. Y.; Swanson, J. A., \& Cheng, H. (2011). State of research on giftedness and gifted education: A survey of empirical studies published during 1998-2010 (april). Gifted Child Quarterly, 55(2), 126-138. doi: 10.1177/0016986210397831

Del Prette, A., \& Del Prette, Z. A. P. (2001). Psicologia das relações interpessoais: Vivências para o trabalho em grupo (6th ed.). Petrópolis, RJ: Vozes.

Del Prette, Z. A. P., \& Del Prette, A. (2005). Psicologia das habilidades sociais na infância: Teoria e prática. Petrópolis, RJ: Vozes.

Del Prette, Z. A. P., \& Del Prette, A. (2008). Um sistema de categorias de habilidades sociais educativas. Paidéia, 18(41), 517-530. doi: 10.1590/ S0103-863X2008000300008

Del Prette, Z. A. P., \& Del Prette, A. (2009). Avaliação de habilidades sociais: Bases conceituais, instrumentos e procedimentos. In: A. Del Prette, \& Z. A. P. Del Prette (Eds.), Psicologia das habilidades sociais: Diversidade teórica e suas implicações (pp. 187-229). Petrópolis: Vozes.

Feitosa, F. B. (2013). Habilidades sociais e sofrimento psicológico. Arquivos Brasileiros de Psicologia, 65(1), 38-50. Retrieved from http://pepsic.bvsalud. org/scielo.php?script=sci_arttext\&pid=S1809-52672013000100004\&ln $\mathrm{g}=\mathrm{pt} \& \mathrm{t} \operatorname{lng} \mathrm{g}=\mathrm{pt}$.

Field, T., Harding, J., Yando, R., Gonzales, K., Lasko, D., Bendell, D., \& Marks, C. (1998). Feelings and attitudes of gifted students. Adolescence, 33(130), 331-342.

Freeman, J. (1998). The education of the very able: Current international research. London: The Stationery Office.

Frydenberg, E. (1997). Adolescent coping: Theorical and research perspective. New York: Routledge. 
Gagné, F. (2005). From gifts to talents. In R. Sternberg \& J. Davidson (Eds.) Conceptions of giftedness (2nd ed., pp. 98-119). New York: Cambridge University Press.

Gagné, F. (2009). Building gifts into talents: Detailed overview of the DMGT 2.0. In B. MacFarlane \& T. Stambaugh (Eds.), Leading change in gifted education: The festschrift of Dr. Joyce VanTassel-Baska (pp. 61-80). Waco, TX: Prufrock Press.

Galloway, B., \& Porath, M. (1997). Parent and teacher views of gifted children's social abilities. Roeper Review, 20(2), 118-121. doi: $10.1080 / 02783199709553872$

Gardner, H. (1994). Estruturas da mente:A teoria das inteligências múltiplas (C. Sandra, Trans.). Porto Alegre: Artemed.

Garland, A. F., \& Zigler, E (1999). Emotional and behavioral problems among highly intellectually gifted youth. Roeper Review, 22(1), 41-44. doi: 10.1080/02783199909553996

Gresham, F. M., \& Elliott, S. N. (1990). Social skills rating system: Manual. Circle Pines, MN: American Guidance Service.

Gross, M. U. M. (2002). Social and emotional issues for exceptionally intellectually gifted students. In M. Neihart, S. M. Reis, N. M. Robinson, \& S. M. Moon (Eds.), The social and emotional development of gifted children: What do we know? (pp. 19-30). Waco, TX: Prufrock Press.

Guenther, Z. C. (2007). Centros comunitários para desenvolvimento de talentos. Revista Educação Especial, Santa Maria, 30(2), 120-130. doi: 10.5902/1984686X

Guenther, Z. C. (2006). Dotação e talento: Reconhecimento e identificação. Revista Educação Especial, Santa Maria, 28(2), 195-208.

Hallahan, D. P., \& Kauffman, J. M. (2003). Exceptional learners: Introduction to special education. Boston: Allyn and Bacon.

Howard-Hamilton, M., \& Franks, B. A. (1995). Gifted adolescents: Psychological behaviors, values, and developmental implications. Roeper Review, 17(3), 186-191.

Lehman, E. B., \& Erdwins, C. J. (2004). The social and emotional adjustment of young intellectually gifted children. In S. Moon (Ed.), Social/emotional issues, underachievement and counseling of gifted and talented students (pp. 1-8). Thousand Oaks: Corwin.

McCallister, C., Nash, W. R., \& Meckstroth, E. (1996). The social competence of gifted children: Experiments and experience. Roeper Review, 18(4), 273276. doi: 10.1080/02783199609553758

Medeiros, C. P., \& Loureiro, S. R. (2004). Observação clínica do comportamento de crianças com queixa de dificuldade de aprendizagem. In E. M. Marturano, M. B. M. Linhares, \& S. R. Loureiro (Eds.), Vulnerabilidade e proteção: Indicadores na trajetória do desenvolvimento escolar (pp. 107-136). São Paulo: Casa do Psicólogo.

Merrell, K. W., Gill, S. J., McFarland, H., \& MacFarland, T. (1996). Internalizing symptoms of gifted and non-gifted elementary-age students: A comparative validity study using the internalizing symptoms scale for children. Psychology in the Schools, 33(3), 185-191.

Moon, S. M. (2004). Social/emotional issues, underachievement, and counseling of gifted and talented students. Thousand Oaks: Corwin.

Moon, S. M. (2009). Myth 15: High-ability students don't face problems and challenges. Gifted Child Quarterly, 53(4), 274-276. doi: 10.1177/0016986209346943

Nail, J. M., \& Evans, J. G. (1997). The emotional adjustment of gifted adolescents: A view of global functioning. Roeper Review, 20(1), 18-21.

Neihart, M. (1999). The impact of giftedness on psychological well-being: What does the empirical literature say? Roeper Review, 22(1), 10-17. doi:10.1080/02783199909553991

Norman, A. D., Ramsay, S. G., Roberts, J. L., \& Martray, C. R. (2000). Effects of social setting, self-concept, and relative age on the social status of moderately and highly gifted students. Roeper Review, 23(1), 34-39.

Pavarino, M. G., Del Prette, A., \& Del Prette, Z. A. P. (2005). Agressividade e empatia na infância: Um estudo correlacional com pré-escolares. Interação em Psicologia, 9(2), 215-225. doi: 10.5380/psi.v9i2.4799
Peterson, S. J. (2009). Myth 17: Gifted and talented individuals do not have unique social and emotional needs. Gifted Child Quarterly, 53(4), 280-282. doi: $10.1177 / 0016986209346946$

Preuss, L. J., \& Dubow, E. F. (2004). A comparison between intellectually gifted and typical children in their coping responses to a school and a peer stressor. Roeper Review, 26, 105-111. doi: 10.1080/02783190409554250

Renzulli, J. S. (1998). The three-ring conception of giftedness. In S. M. Baum, S. M. Reis, \& L. R. Maxfield (Eds.), Nurturing the gifts and talents of primary grade students (pp.1-25). Mansfield Center, CT: Creative Learning Press.

Richards, J., Encel, J., \& Shute, R. (2003). The emotional and behavioral adjustment of intellectually gifted adolescents: A multi-dimensional, multi-informant approach. High Ability Studies, 14(2), 153-163. doi: $10.1080 / 1359813032000163889$

Robinson, N. M., \& Noble, K. D. (1992). Social-emotional development and adjustment of gifted children. In W. Wang, M. Reynolds, \& H. Walberg (Eds.), Handbook of special education. Research and practice (Vol. 4, pp. 5776). Oxford, UK: Pergamon.

Silverman, L. K. (2002). Asynchronous development. In M. Neihart, S. M. Reis, N. M. Robinson, \& S. M. Moon (Eds.), The social and emotional development of gifted children: What do we know? (pp. 31-40). Waco, TX: Prufrock Press.

Sowa, C. J., McIntire, J., May, K. M., \& Bland, L. (1994). Social and emotional adjustment themes across gifted children. Roeper Review, 17, 95-98. doi: $10.1080 / 02783199409553633$

Sternberg, R. L. (2003). WICS as a Model of Giftedness. High Abilities Studies, 14(2), 109-137. doi: 10.1080/1359813032000163807

Swiatek, M. A. (1995). An empirical investigation of the social coping strategies used by gifted adolescents. Gifted Child Quarterly, 39(3), 154-161.

Versteynen, L. (2001). Issues in the social and emotional adjustment of gifted children: what does the literature say? The New Zealand Journal of Gifted Education, 13(1), 1-8. Retrieved from http://www.giftedchildren.org.nz/ apex/v13art04.php

Webb, J. T. (1993). Nurturing social-emotional development of gifted children. In K. A. Heller, F. J. Mönks \& A. H. Passow (Orgs.), International handbook of research and development of giftedness and talent (pp. 525-538). Oxford: Pergamon. 
Maria Luiza Pontes de França-Freitas, Doutora em Psicologia pela Universidade Federal de São Carlos (UFSCAR), é Psicóloga Escolar Educacional da Universidade Federal do Rio Grande do Norte (UFRN). Endereço para correspondência: Escola de Ciências e Tecnologia (ECT) / Universidade Federal do Rio Grande do Norte, Campus Universitário Lagoa Nova, CEP 59078-970, Natal/RN. E-mail: mluizapf@ yahoo.com.br

Almir Del Prette, Doutor em Ciências (Psicologia Experimental) pela Universidade de São Paulo (USP-SP), é Professor Titular Voluntário (aposentado) na Universidade Federal de São Carlos (UFSCAR). E-mail: adprette@ufscar.br

Zilda Aparecida Pereira Del Prette, Doutora em Psicologia Experimental pela Universidade de São Paulo (USP-SP), Pós-Doutora em Habilidades Sociais pela Universidade da Califórnia, Riverside, EUA (UNC), é Professora Titular Voluntária (aposentada) na Universidade Federal de São Carlos (UFSCAR). E-mail: zdprette@ufscar.br 